\title{
Multilateral Control with Haptic Transmission Ratio
}

\author{
Tomoyuki Shimono Student Member (Keio University, shimono@sum.sd.keio.ac.jp) \\ Ryogo Kubo Member (Keio University, kubo@sum.sd.keio.ac.jp) \\ Kouhei OhnishiＳenior Member (Keio University, ohnishi@sd.keio.ac.jp) \\ Seiichiro Katsura Member (Nagaoka University of Technology, katsura@ vos.nagaokaut.ac.jp) \\ Kiyoshi Ohishi Senior Member (Nagaoka University of Technology, ohishi@vos.nagaokaut.ac.jp)
}

Keywords: motion control, haptics, bilateral control, multilateral control, disturbance observer, skill training

In these years, skill education has been a serious problem in various fields. Since haptic information from the real environment is so important for human advanced skill as well as visual and audio information, the only conventional technology of visual and audio information could not realize accurate skill education. Thus, bilateral control that is able to transmit force sensation from the real environment may become a key technology. Then, multilateral control based on bilateral control with disturbance observer that is able to transmit force sensation to several operators may be suitable for skill education system. However, position responses of all systems are synchronized in the plain multilateral control. It is necessary for application of multilateral control to skill education based on haptic information that the influences from the operators are variable according to the trainee's skill acquisition level. Thus, this paper proposes multilateral control with the transmission ratio (TR) that is able to be designed according to the trainee's skill acquisition level.

Fig. 1 shows the proposed multilateral control with transmission ratio. There are two kinds of transmission ratio. One is the transmission ratio of force information $\mathbf{T} \mathbf{R}^{f}$. The other is the transmission ratio of position information $\mathbf{T R}^{p}$. Then, as the results, five types of multilateral control are able to be realized by designing the transmission ratio. $\mathbf{T R}_{i}^{f}$ means the transmission ratio of force information for $i$-th master system. $\mathbf{T R}_{i}^{p}$ means the transmission ratio of position information for $i$-th master system. Fig. 2 shows the design model of transmission ratio for realization of five types of multilateral control.

(1) Plain multilateral control

$$
\mathbf{T R}_{i}^{f}=1.0, \quad \mathbf{T R}_{i}^{p}=1.0
$$

The design model for plain multilateral control is shown as a black circle in Fig. 2.

(2) Position dimension corresponding multilateral control with TR (Position corresponding)

$$
\mathbf{T R}_{i}^{f} \text { : given, } \quad \mathbf{T R}_{i}^{p}=1.0
$$

The design model for position dimension corresponding multilateral control with TR is shown as a thin solid line in Fig. 2.

(3) Impedance corresponding among master systems multilateral control with TR (Impedance corresponding)

$$
\mathbf{T R}_{i}^{f}: \text { given, } \quad \mathbf{T R}_{i}^{p}=\frac{1}{\mathbf{T R}_{i}^{f}}
$$

The design model for impedance corresponding among master systems multilateral control with TR is shown as a dashed line in Fig. 2.
(4) Operationality corresponding among master systems multilateral control with TR (Operationality corresponding)

$$
\mathbf{T R}_{i}^{f} \text { : given, } \quad \mathbf{T R}_{i}^{p}=\mathbf{T R}_{i}^{f}
$$

The design model for operationality corresponding among master systems multilateral control with TR is shown as a dotted line in Fig. 2.

(5) Force dimension corresponding multilateral control with TR (Force corresponding)

$$
\mathbf{T R}_{i}^{f}=1.0, \quad \mathbf{T R}_{i}^{p}: \text { given }
$$

The design model for force dimension corresponding multilateral control with TR is shown as a heavy solid line in Fig. 2.

Finally, the experimental results are shown in order to verify the validity of the proposed methods in the paper.

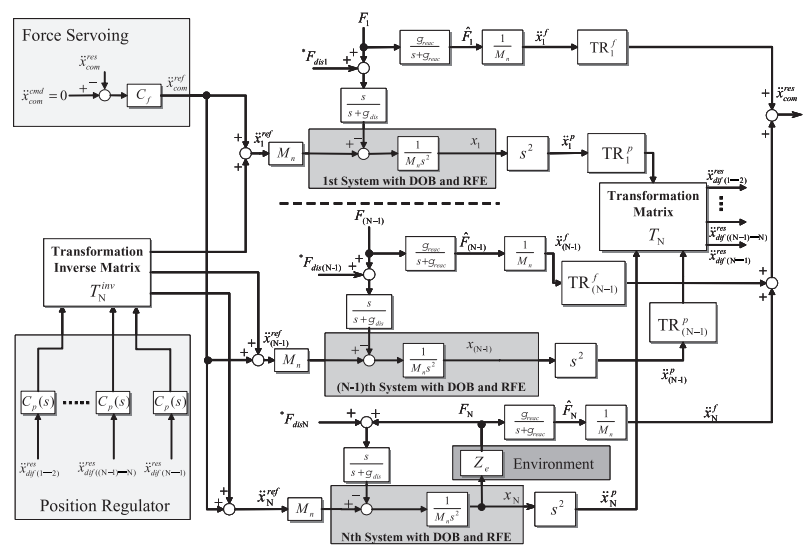

Fig. 1. Multilateral control system with TR

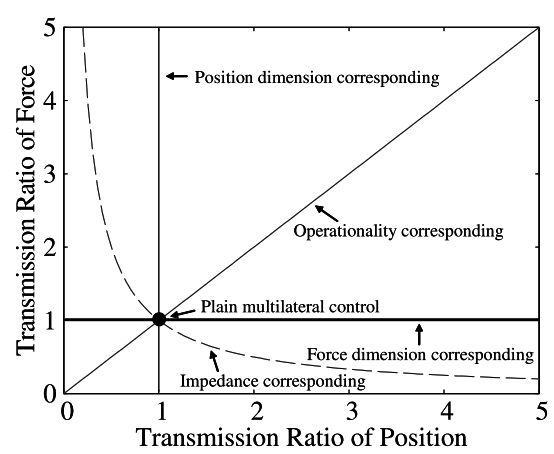

Fig. 2. Design of transmission ratio 


\title{
触覚伝達率を実装したマルチラテラル制御
}

\author{
学生員下野 誠通* 正員 久保 亮吾* \\ 上級会員 大西 公平* 正 員 桂 誠一郎** \\ 上級会員 大石 潔**
}

\begin{abstract}
Multilateral Control with Haptic Transmission Ratio
Tomoyuki Shimono*, Student Member, Ryogo Kubo*, Member, Kouhei Ohnishi*, Senior Member,

Seiichiro Katsura**, Member, Kiyoshi Ohishi**, Senior Member
\end{abstract}

Skill education has been a serious problem in various fields. Since haptic information from the real environment is so important for human advanced skill as well as visual and audio information, the only conventional technology of visual and audio information could not realize accurate skill education. Thus, bilateral control that is able to transmit force sensation from the real environment may become a key technology. Then, multilateral control based on bilateral control that is able to transmit force sensation to several operators is suitable for skill education system. However, it is necessary for application of multilateral control to skill education based on haptic information that the influences from the operators are variable according to the trainee's skill acquisition level. Thus, this paper proposes multilateral control with the transmission ratio that is able to be designed according to the trainee's skill acquisition level. Then, five types of multilateral control are realized by designing the transmission ratio. Finally, the experiments results are shown in order to verify the validity of the proposed method.

キーワード：モーションコントロール，ハプティクス，バイラテラル制御，マルチラテラル制御，外乱オブザーバ，技術教育

Keywords: motion control, haptics, bilateral control, multilateral control, disturbance observer, skill training

\section{1. 序 論}

近年, 高齢化などの理由から様々な分野において熟練技 術者の減少が大きな問題となってきている。またこれに伴 い，若手技術者の技術教育が大きな課題として挙げられて いる。この社会的課題に対して，もし技術教育システムと いった科学的な技術伝承手法が実現されれば，一つの解決 策となり得るであろう。しかしながら既存の視覚情報およ び聴覚情報の伝達・保存・再現技術のみでは, 熟練者の技 術伝承システムの実現には不十分である。これは熟練者の 技術のほとんどは，道具や器具，および装置といったある 種のシステムを用いた動作であり，操作するシステムを通 じて得られる実環境からの触覚情報が大変重要な感覚情報

\footnotetext{
*慶應義塾大学理工学部システムデザイン工学科

干 223-8522 横浜市港北区日吉 3-14-1

Department of System Design Engineering, Keio University

3-14-1, Hiyoshi, Kouhoku, Yokohama 223-8522

** 長岡技術科学大学電気系

干940-2188 長岡市上富岡町 1603-1

Department of Electrical Engineering, Nagaoka University of Technology

1603-1, Kamitomiokamachi, Nagaoka 940-2188
}

となるからである。したがって，高度な熟練技術の科学的 伝承システムの実現のためには，人工的に実環境からの触 覚情報を伝達する技術が大変重要であるといえる。しかし， 触覚情報は作用 · 反作用の双方向情報であるため, システ ムを通じて人工的に操作者に触覚情報を伝達するためには, システムもまた同時に双方向性を有していなければならな い。まずシステムが双方向性を有するための制御手法とし ては，マスタシステムとスレーブシステムからシステムを 構成するバイラテラル制御が挙げられる。 バイラテラル制御に関しては今日までに非常に多くの研 究が行われてきた。B. Hannaford はマスタ・スレーブの位 置と力の関係をハイブリッド行列を用いて定式化を行い, 理想条件を提案した ${ }^{(1)}$ 。また, Hannafordの提案したバイ ラテラル制御のマスタ・スレーブ間の理想条件はその後拡 張され, D.A. Lawrence によって安定性と透明性として議 論された(2)。また，Hashtrudi-Zaadらによってマスタ・ス レーブ間で透明性を獲得するためのバイラテラル制御系が 提案された ${ }^{(3)}$ (4)。横小路らもまたマスタ・スレーブ間で透 明性を確保するための制御系を提案した ${ }^{(5)}$ 。小菅らはイン ピーダンス制御の概念を拡張した Task-Oriented 仮想ツー ルを導入した制御系を提案した ${ }^{(6)}$ 。しかしながら，これま 
でに提案されてきたバイラテラル制御は単一のマスタシス テムと単一のスレーブシステムから構成されていた。触覚 情報に基づいた科学的技術教育を行うためには，スレーブ システムが環境と接触した際の触覚情報を熟練者と訓練者 といった複数の操作者が同時に知覚する必要があるため, 複数のマスタシステムに同時に触覚情報を伝達しなければ ならない。したがって，マルチラテラル制御における作用・ 反作用則の人工的な実現が必要不可欠である。

既往の研究としてまずはじめに，バイラテラル制御に基 づき通信遅延を含んだ場合の複数ロボットの制御手法が提 案された(7) (8)。また複数のマスタシステムと複数のスレー ブシステムからシステムを構成し，協調遠隔操作を行うた めの手法も提案された ${ }^{(9)}$ 。しかしながら，実環境からの鮮 明な力覚情報の伝達を実現するためには，すべてのシステ ム間において作用・反作用則を厳密に実現する必要がある。 そこで加速度制御に基づくバイラテラル制御を拡張したマ ルチラテラル制御による作用・反作用則の実現手法が提案 された ${ }^{(10)}$ 。

マルチラテラル制御はすべてのシステム間での双方向情 報伝達が可能なため, 様々な技術応用が期待できるが，一般 的なマルチラテラル制御ではすべてのシステム間で位置応 答は同一化されてしまう。したがってマルチラテラル制御 において，各システムに情報を分離して伝達する手法に関 しても研究が行われてきている。まずはじめに将来的な触 覚情報通信を目的とし，アイデンティティ比を用いること で位置応答を印加された力の比に応じて各システムに対し て分離するマルチラテラル制御手法が提案された ${ }^{(11)}$ 。これ に対して，技術教育にマルチラテラル制御を応用するため には，訓練者の技術習得レベルに応じて，教育を行う熟練 者からのシステムへの影響度を変化させることが望まれる。 これまでに技術教育への応用を目的として Shared-Control 手法が提案されたが，マスタシステムはジョイスティックで あったため, 厳密な操作技術の教育は実現できなかった ${ }^{(12)}$ 。 そこで本論文では，触覚情報に基づいた科学的技術教育シ ステム実現のための基礎技術として，各操作者からの影響 度を調節するための伝達率というパラメータを導入した新 しいマルチラテラル制御系を提案する。

本論文の構成を以下に述べる。まず続く第 2 章では，本 論文で提案するマルチラテラル制御系に実装されている外 乱オブザーバについて簡易な説明を行う。そして第 3 章で, 将来的な触覚情報に基づいた技術教育への応用を目的とし て，触覚伝達率を導入したマルチラテラル制御手法を提案 する。また，提案する伝達率の設計についても考察を行う。 第 4 章では，提案手法の有効性を確認するために実験結果 を示す。そして最後に第 5 章において，結論として本論文 をまとめる。

本章の最後に，本論文で用いる主なパラメータや添え字 の定義を表 1 に示す。
表 1 パラメー夕定義一覧

Table 1. List of parameter definition.

\begin{tabular}{c|l}
\hline$F$ & Force \\
$x$ & Position \\
$\dot{x}$ & Velocity \\
$\ddot{x}$ & Acceleration \\
$M$ & Mass \\
TR & Haptic transmission ratio \\
$C_{p}$ & Position regulator \\
$C_{f}$ & Force servoing \\
$K_{t}$ & Force coefficient \\
$D$ & Viscosity coefficient \\
$I_{a}$ & Current value \\
$g_{d i s}$ & Cut-off frequency of disturbance observer \\
$g_{\text {reac }}$ & Cut-off frequency of reaction force estimation \\
$s$ & Laplace operator \\
(superscript) cmd & Command value \\
(superscript) ref & Reference value \\
(superscript) & Estimated value \\
(superscript) res & Response value \\
(superscript) $f$ & Value associated with force information \\
(superscript) $p$ & Value associated with position information \\
(subscript) $n$ & Nominal value \\
(subscript) com & Common mode \\
(subscript) dif & Differential mode \\
\hline &
\end{tabular}

\section{2. 外乱オブザーバ}

外乱オブザーバ (DOB : Disturbance Observer) はカセン サレスでシステムの外乱力を観測することができる(13)。直 動型リニアモータをアクチュエータとして想定した場合の 外乱オブザーバのブロック線図を図 1 に示す。

外乱オブザーバにおいて, 外乱力は (1) 式のように表さ れる。

$$
\begin{aligned}
F_{d i s}= & F_{e x t}+F_{i n t}+F_{C}+D \dot{x} \\
& +\left(M-M_{n}\right) \ddot{x}+I_{a}^{r e f}\left(K_{t n}-K_{t}\right)
\end{aligned}
$$

ここで， $F_{\text {ext }}$ はシステムに外部から印加される外乱力を, $F_{i n t}$ は内部干渉力を, $F_{C}$ はクーロン摩擦力を, $D \dot{x}$ は粘性 摩擦力をそれぞれ表すものとする。また， $\left(M-M_{n}\right) \ddot{x}$ の項 は慣性変動による外乱力を表し, $I_{a}^{r e f}\left(K_{t n}-K_{t}\right)$ の項は推力 リップルを表している。そして，外乱力は外乱オブザーバ によりローパスフィルタを通過して (2) 式のように推定さ れる。

$$
\hat{F}_{d i s}=\frac{g_{d i s}}{s+g_{d i s}} F_{d i s}
$$

推定された外乱力のフィードバックループを設けると，外 乱の低周波成分を補償することができ，ロバスト性を得る ことができる。したがって，外乱オブザーバを用いること でロバスト性を確保することができる。このとき，システ ムには外乱オブザーバによって外乱の低周波成分が補償さ れて印加されることとなり, 等価的にはハイパスフィルタ を通過して外乱が印加されることとなる。

外乱オブザーバはまた，(3) 式のように力センサを用いる ことなく反力のみを推定することが可能となる ${ }^{(14)}$ 。 


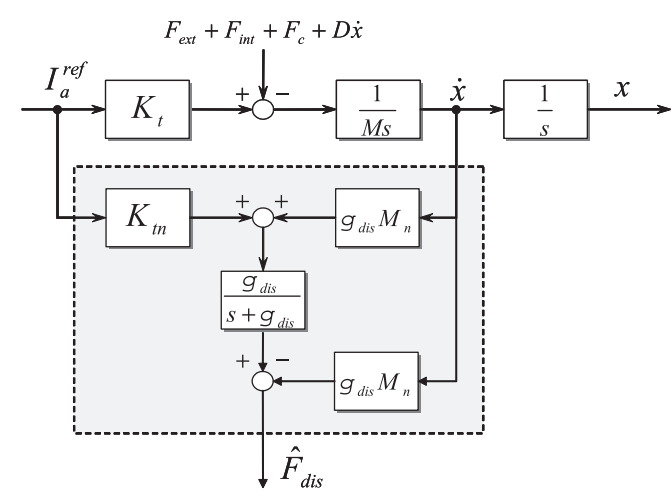

図 1 外乱オブザーバ

Fig. 1. Disturbance observer (DOB).

$$
\hat{F}_{\text {ext }}=\frac{g_{\text {reac }}}{s+g_{\text {reac }}} F_{\text {ext }}
$$

この機能を外乱オブザーバの反力推定機能 (RFE：Reaction Force Estimation）と本論文では呼ぶこととする。外乱オブ ザーバはそのカットオフ周波数を安定範囲内において上げ ることによって，できるだけ速く反力を推定することがで きる ${ }^{(14)(15)}$ 。

\section{3. 伝達率を実装したマルチラテラル制御}

本論文では操作者が直接操作するシステムをマスタシス テムとし，マルチラテラル制御を通じて遠隔環境と接触す るシステムをスレーブシステムと定義する。そして本章で は，複数のマスタシステムと単一のスレーブシステムから 構成されるマルチラテラル制御システムについて検討する。 すなわち $(N-1)$ 人の操作者が $(N-1)$ 台のマスタシステ ムをそれぞれ操作し，一つのスレーブシステム（ $N$ 番目と する）が実環境と接触する場合を考察する。また本論文で は，マルチラテラル制御は外乱オブザーバによって実現さ れる加速度制御に基づいて設計される。

このとき，マルチラテラル制御において，複数の操作者 が複数のマスタシステムにそれぞれ加える作用力と単一の スレーブが実環境と接触して受ける反作用力との間に，作 用反作用の法則を人工的に成立させるための目標式として， システムの力の関係は (4) 式のように表される。

$$
F_{1}+F_{2}+\cdots+F_{N}=0(N: \text { Natural number })
$$

しかしながら技術教育システムにマルチラテラル制御を応 用するためには，訓練者の技術習得レベルに応じて，各操 作者からのシステムへの影響度を変化させる必要がある。 そこで, 各操作者からシステムへ印加される入力の影響度 を調節するための力の伝達率 $\mathbf{T R}^{f}$ (Transmission Ratio）を 導入する。提案する力の伝達率 $\mathbf{T R}^{f}$ は力の情報の伝達の割 合を決定する要素であるので，以下の条件を持つ。

$$
0.0 \leq \mathbf{T R}^{f}
$$

このとき，伝達率を用いると力に関する目標式は (6) 式の

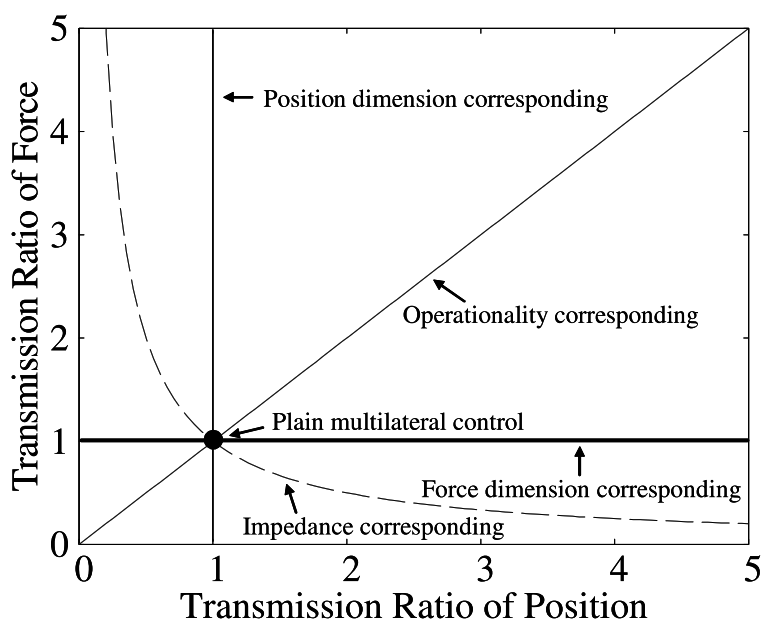

図 2 伝達率の設計

Fig. 2. Design of transmission ratio.

ようになる。

$$
\mathbf{T R}_{1}^{f} F_{1}+\mathbf{T R}_{2}^{f} F_{2}+\cdots+\mathbf{T R}_{(N-1)}^{f} F_{(N-1)}+F_{N}=0
$$

一方で，すべてのシステムがお互い追従し合うための位置 に関する目標式は (7) 式のように示される。

$$
x_{1}=x_{2}=\cdots=x_{(N-1)}=x_{N} \cdot
$$

またマルチラテラル制御においては，力情報の伝達率のみ ならず位置情報の伝達率も導入することで様々な応用が期 待できる。したがって，位置の情報に関する伝達率 $\mathbf{T R}^{p}$ も 併せて導入する。提案する位置情報の伝達率は次式のよう な条件を持つ。

$$
0.0 \leq \mathbf{T R}^{p}
$$

このとき，伝達率を用いると位置に関する目標式は (9) 式 のようになる。

$$
\mathbf{T R}_{1}^{p} x_{1}=\mathbf{T R}_{2}^{p} x_{2}=\cdots=\mathbf{T R}_{(N-1)}^{p} x_{(N-1)}=x_{N} \cdots \cdots \cdots
$$

結果として, これらの力の伝達率と位置の伝達率を設計 することで，それぞれの伝達率の設計により，従来手法で ある一般的なマルチラテラル制御 ${ }^{(10)}$ の他に, 以下のような 4 種類のマルチラテラル制御を実現することができる。ま た, $\mathbf{T R}_{i}^{f}$ は $i$ 番目のマスタシステムの力の伝達率を表し, $\mathbf{T R}_{i}^{p}$ は $i$ 番目のマスタシステムの位置の伝達率を表すもの とする。このとき, 各マスタシステムのそれぞれの伝達率 は独立である。伝達率の設計モデルを図 2 に示す。

（1）一般的なマルチラテラル制御（Plain multilateral control)

$$
\mathbf{T R}_{i}^{f}=1.0, \quad \mathbf{T R}_{i}^{p}=1.0
$$

一般的なマルチラテラル制御の伝達率設計は, 図 2 におい ては黒丸点によって示されている。このとき, 全てのマス夕 
システムの力の伝達率 $\mathbf{T R}_{1}^{f}, \mathbf{T R}_{2}^{f}, \cdots, \mathbf{T R}_{(N-1)}^{f}$ および全て のマスタシステムの位置の伝達率 $\mathbf{T R}_{1}^{p}, \mathbf{T R}_{2}^{p}, \cdots, \mathbf{T R}_{(N-1)}^{p}$ は 1.0 に設定される。

（2）伝達率を用いた位置次元一致型マルチラテラル制 御 (Position dimension corresponding)

$$
\mathbf{T R}_{i}^{f} \text { : given, } \quad \mathbf{T R}_{i}^{p}=1.0
$$

伝達率を用いた位置次元一致型マルチラララル制御のため の伝達率設計は, 図 2 に扔いては細い実線によって示されて いる。このとき, 全てのマスタシステムの力の伝達率 $\mathbf{T R}_{1}^{f}$, $\mathbf{T R}_{2}^{f}, \cdots, \mathbf{T R}_{(N-1)}^{f}$ は独立に任意の值に設定できる。それに 対して, 全てのマスタシステムの位置の伝達率 $\mathbf{T R}_{1}^{p}, \mathbf{T R}_{2}^{p}$, $\cdots, \mathbf{T R}_{(N-1)}^{p}$ は 1.0 に設計しなければならない。すなわち, 位置次元一致型マルチラテラル制御を実現するときには, 全てのマスタシステムの伝達率が図 2 の細い実線上になる ように設計しなければならない。

（3）伝達率を用いたマスタシステム間でのインピーダ ンス一致型マルチラテラル制御 (Impedance corresponding)

$$
\mathbf{T R}_{i}^{f}: \text { given, } \quad \mathbf{T R}_{i}^{p}=\frac{1}{\mathbf{T R}_{i}^{f}}
$$

伝達率を用いたマスタシステム間でのインピーダンス一致 型マルチラテラル制御のための伝達率設計は，図 2 におい ては破線によって示されている。このとき，全てのマスタ システムにおいてインピーダンスを一致させるためには， 各マスタシステムの力の伝達率 $\mathbf{T R}_{1}^{f}, \mathbf{T R}_{2}^{f}, \cdots, \mathbf{T R}_{(N-1)}^{f}$ は任意の值に設定することができる。そして，位置の伝達 率 $\mathbf{T R}_{1}^{p}, \mathbf{T R}_{2}^{p}, \cdots, \mathbf{T R}_{(N-1)}^{p}$ は，対応するそれぞれのマス タシステムの力の伝達率 $\mathbf{T R}_{i}^{f}$ の逆数に設定しなければなら ない。すなわち，インピーダンス一致型マルチラテラル制 御を実現するときには，全てのマスタシステムの伝達率を 図 2 の破線上になるように設計しなければならない。これ により，スレーブシステムが環境と接触した時に，各マス タシステム側で人工的に再現されるインピーダンスが一致 する。つまり，インピーダンス一致型マルチラテラル制御 に扔いては，スレーブシステムが環境と接触した際に，各 マスタシステムに等しい力を印加した場合に， $\frac{\mathbf{T R}_{i}^{f} F_{i}}{x_{i}}$ の値 が等しくなる。

（4）伝達率を用いたマスタシステム間での操作性一致 型マルチラテラル制御（Operationality corresponding）

$$
\mathbf{T R}_{i}^{f} \text { : given, } \quad \mathbf{T R}_{i}^{p}=\mathbf{T} \mathbf{R}_{i}^{f}
$$

伝達率を用いたマスタシステム間での操作性一致型マルチ ラテラル制御のための伝達率設計は, 図 2 に押いては点線 によって示されている。このとき，各マスタシステムの力の 伝達率 $\mathbf{T R}_{1}^{f}, \mathbf{T R}_{2}^{f}, \cdots, \mathbf{T R}_{(N-1)}^{f}$ は任意の值に設定すること ができる。そして，位置の伝達率 $\mathbf{T R}_{1}^{p}, \mathbf{T R}_{2}^{p}, \cdots, \mathbf{T R}_{(N-1)}^{p}$ は，対応するそれぞれのマスタシステムの力の伝達率 $\mathbf{T R}_{i}^{f}$ と等しい值に設定しなければならない。すなわち，操作性
一致型マルチラテラル制御を実現するときには, 全てのマ スタシステムの伝達率を図 2 の点線上になるように設計し なければならない。また本論文では操作性を, 各マスタシ ステムを各操作者が操作する際に感じる操作感覚と定義す る。つまり操作性はフリーモーション時における等価慣性 の逆数を意味する。操作性一致型マルチラテラル制御にお いては, 操作者が印加した実際の力とそれに応じたシステ ムの実際の加速度の比 $\frac{\ddot{x}_{i}}{F_{i}}$ が, 環境と接触していない時に等 しくなる。

（5）伝達率を用いた力次元一致型マルチラテラル制御 (Force dimension corresponding)

$$
\mathbf{T R}_{i}^{f}=1.0, \quad \mathbf{T R}_{i}^{p}: \text { given }
$$

伝達率を用いた力次元一致型マルチラテラル制御のための 伝達率設計は, 図 2 においては太い実線によって示されてい る。このとき, 全てのマスタシステムの位置の伝達率 $\mathbf{T R}_{1}^{p}$, $\mathbf{T R}_{2}^{p}, \cdots, \mathbf{T R}_{(N-1)}^{p}$ は独立に任意の值に設定できる。それ に対して, 全てのマスタシステムの力の伝達率 $\mathbf{T R}_{1}^{f}, \mathbf{T R}_{2}^{f}$, $\cdots, \mathbf{T R}_{(N-1)}^{f}$ は 1.0 に設計しなければならない。すなわち, 力次元一致型マルチラテラル制御を実現するときには, 全 てのマスタシステムの伝達率が図 2 の太い実線上になるよ うに設計しなければならない。

マルチラテラル制御では上記の力の目標と位置の目標と が同時に理想的に達成されることが必要となる。しかしな がら, 力情報と位置情報は次元が異なるために, 単純に和 差計算を行い，その情報をシステム間で伝送することは不 可能である。そこで本論文では, 加速度次元という共通の 次元において力制御と位置制御のそれぞれの目標を統一し, それぞれの目標を同時に達成するための加速度制御に基づ くマルチラテラル制御系を設計する。そこで伝達率を用い た力に関する目標式と，位置に関する目標式を (10), (11) 式のように加速度次元の目標式に変換する。

$$
\begin{aligned}
& \mathbf{T R}_{1}^{f} \ddot{x}_{1}^{f}+\mathbf{T R}_{2}^{f} \ddot{x}_{2}^{f}+\cdots+\mathbf{T R}_{(N-1)}^{f} \ddot{x}_{(N-1)}^{f}+\ddot{x}_{N}^{f}=\ddot{x}_{c o m}^{r e s}=0 \\
& \text {............... (10) } \\
& \mathbf{T R}_{1}^{p} \ddot{x}_{1}^{p}-\mathbf{T R}_{2}^{p} \ddot{x}_{2}^{p}=\ddot{x}_{d i f(1-2)}^{r e s} \rightarrow 0 \\
& \mathbf{T R}_{2}^{p} \ddot{x}_{2}^{p}-\mathbf{T R}_{3}^{p} \ddot{x}_{3}^{p}=\ddot{x}_{\text {dif(2-3) }}^{r e s} \rightarrow 0 \\
& \mathbf{T R}_{(N-1)}^{p} \ddot{x}_{(N-1)}^{p}-\ddot{x}_{N}^{p}=\ddot{x}_{d i f((N-1)-N)}^{r e s} \rightarrow 0 \\
& \ddot{x}_{N}^{p}-\mathbf{T R}_{1}^{p} \ddot{x}_{1}^{p}=\ddot{x}_{\text {dif }(N-1)}^{r e s} \rightarrow 0
\end{aligned}
$$

ここで, $\ddot{x}^{f}$ と $\ddot{x}^{p}$ は力情報と位置情報から得られた加速度次 元の情報であることをそれぞれ表している。力情報からの 加速度次元情報は，(12) 式で表されるように外乱才ブザー バの反力推定機能を通じて得られる。

$$
\ddot{x}^{f}=\frac{1}{M_{n}} \hat{F}_{\text {ext }}
$$

それに対して, 位置情報からの加速度次元情報は (13) 式の ように得られる。 
$\ddot{x}^{p}=s^{2} x$

また位置情報から得られる加速度次元の情報は (13) 式のよ うに 2 階微分より算出するため, どうしても 2 サンプリン グ時間遅れた情報となってしまう。したがって (11) 式にお いて等号ではなく矢印を用いて表現しており，これは位置 情報から得られた加速度次元情報が出来るだけ早く収束し， 定常状態で一致するという目標式を意味している。

また (10) 式は, 加速度次元での力の和の追従值を 0 とし たときの力サーボを示している。そこで本論文では力の目 標を加速度次元に扔いて達成するために次式に示される力 サーボを用いる。

$$
\ddot{x}_{c o m}^{r e f}=C_{f}\left(\ddot{x}_{c o m}^{c m d}-\ddot{x}_{c o m}^{r e s}\right)=-C_{f} \ddot{x}_{c o m}^{r e s} .
$$

また（14）式に示される加速度次元における力サーボを図 3 に表す。この加速度次元に扔ける力の目標を，システムの 和に関する目標式であることから，仮想的なモード空間に おけるコモンモードと呼ぶ。またコモンモードは，外乱と してシステムに印加される外力を加速度次元において制御 するという反力制御を意味している。

これに対して，(11) 式は, 加速度次元での位置の偏差の 目標値を 0 としたときの位置レギュレータを示している。 本論文では位置の目標を加速度次元に扔いて達成するため に次式に示される位置レギュレータを用いる。

$$
\ddot{x}_{d i f}^{r e f}=C_{p}(s) \ddot{x}_{d i f}^{r e s} .
$$

また(15) 式に示される加速度次元における位置レギュレー 夕を図 4 に表す。この加速度次元における位置の目標を,

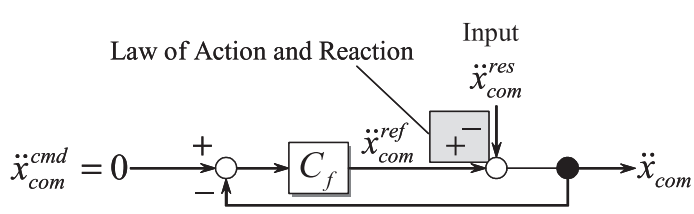

困 3 力サーボ

Fig. 3. Force servoing.

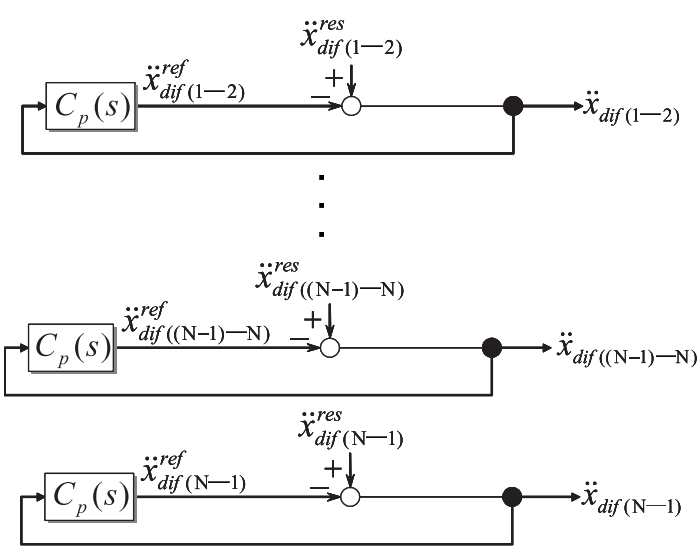

困 4 位置レギュレータ

Fig. 4. Position regulator.
システムの差に関する目標式であることから, 仮想的なモー ド空間に扔けるディファレンシャルモードと呼ぶ。このよ うに, 力と位置の目標をそれぞれ同時に達成するために, 加 速度次元に打いてコモンモードとディファレンシャルモー ドという仮想的なモード空間に配置することで，それぞれ を独立に設計することが可能となる。また, $C_{f}$ と $C_{p}(s)$ は それぞれ力サーボのゲインと位置レギュレータのゲインを 示している。本論文で用いた力サーボのゲイン $C_{f}$ と位置 レギュレータのゲイン $C_{p}(s)$ を(16) 式と (17) 式に示す。

$$
\begin{aligned}
& C_{f}=K_{f} \ldots \ldots \ldots \ldots \ldots \\
& C_{p}(s)=\frac{1}{s^{2}} K_{p}+\frac{1}{s} K_{v}+K_{a}
\end{aligned}
$$

$K_{f}, K_{p}, K_{v}$ および $K_{a}$ は力ゲイン, 位置ゲイン, 速度ゲイ ンおよび加速度ゲインをそれぞれ表している。

また，位置情報から得られた加速度情報の，仮想的なモー ド空間とアクチュエータ空間との空間変換を, 次の変換行列 (Transformation matrix) $\boldsymbol{T}_{N}$ と逆变換行列（Inverse transformation matrix） $\boldsymbol{T}_{N}^{i n v}$ を用いて行う。

$$
\begin{aligned}
& \boldsymbol{T}_{2}=\left[\begin{array}{cc}
1 & -1 \\
-1 & 1
\end{array}\right], \quad \boldsymbol{T}_{2}^{i n v}=\left[\begin{array}{ll}
0 & 1 \\
1 & 0
\end{array}\right] \\
& \boldsymbol{T}_{3}=\left[\begin{array}{ccc}
1 & -1 & 0 \\
0 & 1 & -1 \\
-1 & 0 & 1
\end{array}\right], \quad \boldsymbol{T}_{3}^{i n v}=\left[\begin{array}{lll}
0 & 0 & 1 \\
1 & 0 & 0 \\
0 & 1 & 0
\end{array}\right]
\end{aligned}
$$

$$
\boldsymbol{T}_{N}=\left[\begin{array}{cccccc}
1 & -1 & 0 & 0 & \cdots & 0 \\
0 & 1 & -1 & 0 & \cdots & 0 \\
0 & 0 & 1 & -1 & \cdots & 0 \\
\vdots & & & & & \vdots \\
0 & 0 & \cdots & 0 & 1 & -1 \\
-1 & 0 & 0 & \cdots & 0 & 1
\end{array}\right],
$$

$$
\boldsymbol{T}_{N}^{i n v}=\left[\begin{array}{cccccc}
0 & 0 & 0 & 0 & \cdots & 1 \\
1 & 0 & 0 & 0 & \cdots & 0 \\
0 & 1 & 0 & 0 & \cdots & 0 \\
\vdots & & & & & \vdots \\
0 & 0 & \cdots & 1 & 0 & 0 \\
0 & 0 & \cdots & 0 & 1 & 0
\end{array}\right]
$$

変換行列 $\boldsymbol{T}_{N}$ を用いることで, アクチュエータ空間から仮 想的なディファレンシャルモード空間への空間変換は (19) 式のように実現される。

$$
\left[\begin{array}{c}
\ddot{x}_{d i f(1-2)}^{r e s} \\
\ddot{x}_{\text {dif }}^{r e s}(2-3) \\
\vdots \\
\ddot{x}_{\text {dif }}^{r e s}((N-1)-N) \\
\ddot{x}_{\text {dif }}^{r e s}(N-1)
\end{array}\right]=\boldsymbol{T}_{N}\left[\begin{array}{c}
\mathbf{T R}_{1}^{p} \ddot{x}_{1}^{p} \\
\mathbf{T R}_{2}^{p} \ddot{x}_{2}^{p} \\
\vdots \\
\mathbf{T R}_{(N-1)}^{p} \ddot{x}_{(N-1)}^{p} \\
\ddot{x}_{N}^{p}
\end{array}\right]
$$

それに対し $\boldsymbol{T}_{N}^{i n v}$ を用いることで, 仮想的なディファレンシャ 


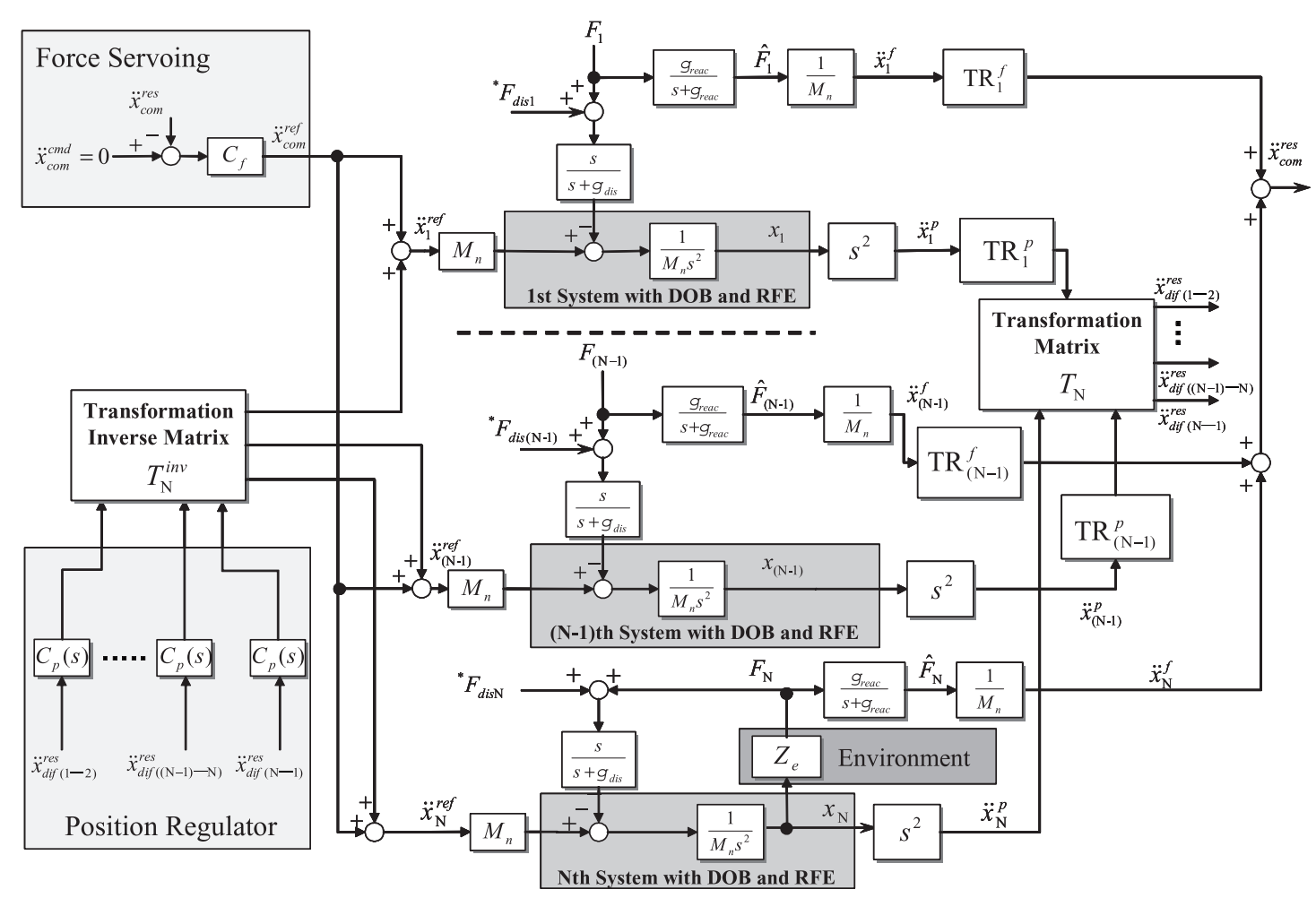

図 5 触覚伝達率を実装したマルチラテラル制御系

Fig. 5. Multilateral control system with haptic transmission ratio.

ルモード空間からアクチュエータ空間への空間変換は (20) 式のように達成される。

$$
\left[\begin{array}{c}
\ddot{x}_{d i f 1}^{r e f} \\
\ddot{x}_{d i f 2}^{r e f} \\
\vdots \\
\ddot{x}_{d i f(N-1)}^{r e f} \\
\ddot{x}_{d i f N}^{r e f}
\end{array}\right]=\boldsymbol{T}_{N}^{i n v}\left[\begin{array}{c}
\ddot{x}_{d i f(1-2)}^{r e f} \\
\ddot{x}_{d i f(2-3)}^{r e f} \\
\vdots \\
\ddot{x}_{d i f((N-1)-N)}^{r e f} \\
\ddot{x}_{d i f(N-1)}^{r e f}
\end{array}\right]
$$

そして，ディファレンシャルモードにおける加速度参照值 とコモンモードにおける加速度参照值が合計されて，(21) 式のように各システムに対する加速度参照值となる。

$$
\ddot{x}_{N}^{r e f}=\ddot{x}_{c o m}^{r e f}+\ddot{x}_{d i f N}^{r e f}
$$

本論文で提案する伝達率を実装したマルチラテラル制御系 のブロック線図を図 5 に示す。

\section{4. 実 験}

〈4·1〉実験設定本研究における実験装置を図 6 に示 す。この実験装置はロッド型リニアモータがアクチュエー

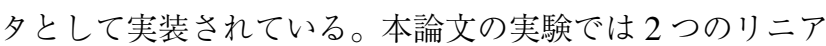
モータをマスタシステムとして，1つのリニアモータをス レーブシステムとして用いた。そして，二人の操作者が二 つのマスタシステムを直接それぞれ操作し, 残りのスレー ブシステムを発泡スチロール製の環境に接触させた。そし て提案手法の伝達率を様々に設計することで，従来手法で ある一般的なマルチラテラル制御のほかに，4 種類の伝達率

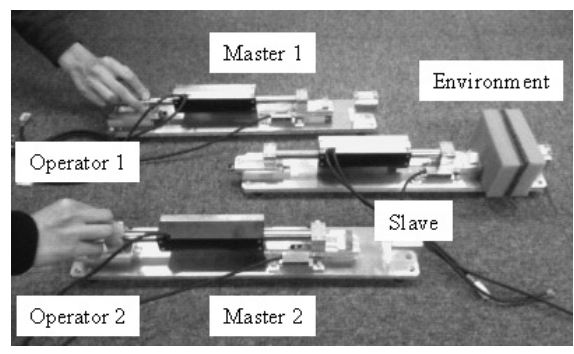

四 6 実験システム

Fig. 6. Experimental system.

表 2 実験における制御パラメー夕設定

Table 2. Control parameters in the experiment.

\begin{tabular}{|c|c|c|}
\hline Parameter & Description & Value \\
\hline$K_{p}$ & Position gain & 900 \\
\hline$K_{v}$ & Velocity gain & 60 \\
\hline$K_{a}$ & Acceleration gain & 0.1 \\
\hline$K_{f}$ & Force gain & 0.1 \\
\hline$K_{t n}$ & Force coefficient & $32.5 \mathrm{~N} / \mathrm{A}$ \\
\hline$M_{n}$ & Mass & $0.50 \mathrm{~kg}$ \\
\hline$g_{\text {dis }}, g_{\text {reac }}$ & $\begin{array}{c}\text { Cut-off frequency } \\
\text { of disturbance observer }\end{array}$ & $500 \mathrm{rad} / \mathrm{s}$ \\
\hline
\end{tabular}

を導入したマルチラテラル制御手法について考察を行った。 なおシステムの制御プログラムは C 言語によって書かれ, コンピュータのオペレーションシステムには RT-Linux3.1 が用いられている。実験はサンプリング時間を $0.1 \mathrm{~ms}$ とし て行われる。表 2 にその他の実験パラメータを示す。 


\section{$\langle 4 \cdot 2\rangle$ 実験結果}

$\langle\mathbf{4} \cdot \mathbf{2} \cdot \mathbf{1}\rangle$ 一般的なマルチラテラル制御における実験結 果 まずはじめに, 従来手法である一般的なマルチラテ ラル制御における実験結果を図 7 に示す。また網掛け部は 発泡スチロール製の環境と接触している状態を示している。 従来手法であるマルチラテラル制御は, 提案する伝達率を すべて 1.0 に設定することで容易に実現できる。このとき, 位置情報と力情報のすべてが完全に伝達されるため, すべ てのシステムの位置応答が一致し，すべてのシステム間で 作用反作用則が人工的に実現されていることがわかる。つ まりマルチラテラル制御における目標式である，(4) 式と (7) 式が成立されていることがわかる。

$\langle\mathbf{4} \cdot \mathbf{2} \cdot \mathbf{2}\rangle$ 位置次元一致型マルチラテラル制御の実験結 果次に伝達率を導入した位置次元一致型マルチラテラ ル制御の実験結果を図 8 に示す。また網掛け部は発泡スチ ロール製の環境と接触している状態を示している。本実験 では, マスタシステム 2 の力情報の伝達率 $\mathbf{T R}_{2}^{f}$ を 0.5 に設 計し, そのほかの伝達率を 1.0 とした。実験結果より, 操 作者よりマスタシステム 2 に印加された力の半分だけがマ ルチラテラルシステム全体に伝達されていることがわかり， マルチラテラルシステムにおいて (6) 式が満たされている と言える。またそれに対して位置応答に関しては，すべて のシステムで一致されていることがわかる。したがって， 伝達率を導入した位置次元一致型マルチラテラル制御では, 力情報の伝達率のみを訓練者の技術習得レベルに応じて変 化させて設計することで, 訓練者の影響度を変化させなが ら熟練動作を学ぶことができる。

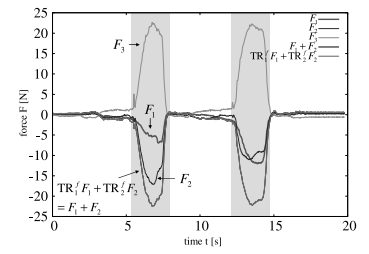

(a) Force responses $\mathbf{T R}_{1}^{f}=1.0, \mathbf{T R}_{2}^{f}=1.0$ $\mathbf{T R}_{1}^{p}=1.0, \mathbf{T R}_{2}^{p}=1.0$

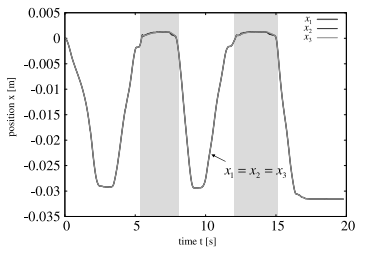
$\mathbf{T R}_{1}^{f}=1.0, \mathbf{T R}_{2}^{f}=1.0$ $\mathbf{T R}_{1}^{p}=1.0, \mathbf{T R}_{2}^{p}=1.0$ (b) Position responses

図 7 一般的なマルチラテラル制御による実験結果

Fig. 7. Experimental results on plain multilateral control.

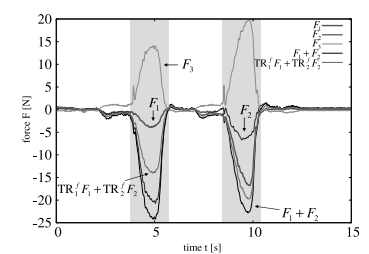

(a) Force responses

$\mathbf{T R}_{1}^{f}=1.0, \mathbf{T R}_{2}^{f}=0.5$

$\mathbf{T R}_{1}^{p}=1.0, \mathbf{T R}_{2}^{p}=1.0$

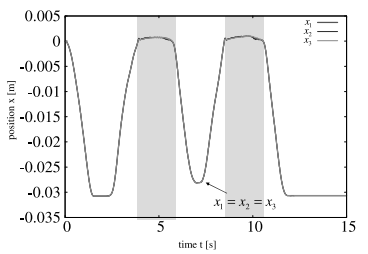

(b) Position responses $\mathbf{T R}_{1}^{f}=1.0, \mathbf{T R}_{2}^{f}=0.5$ $\mathbf{T R}_{1}^{p}=1.0, \mathbf{T R}_{2}^{p}=1.0$
図 8 位置次元一致型マルチラテラル制御の実験結果

Fig. 8. Experimental results on multilateral control with transmission ratio for position dimension corresponding.
〈4·2·3〉 マスタ間でのインピーダンスー致型マルチラ テラル制御の実験結果図 9 にマスタ間でのインピーダ ンス一致型マルチラテラル制御の実験結果を示す。また網 掛け部は発泡スチロール製の環境と接触している状態を示 しており, 図 9(c) は各システムでのインピーダンス応答を 示している。本実験では, マスタシステム 2 の力の情報の 伝達率 $\mathbf{T R}_{2}^{f}$ を 0.5 に, 位置の情報の伝達率 $\mathbf{T R}_{2}^{p}$ を 2.0 に設 計した。これにより，スレーブシステムが環境と接触した とき, 操作者が各マスタシステムに等しい力を印加すると, マスタシステム側で再現されるインピーダンスがマスタシ ステム間で一致する。しかし，この再現されたインピーダ ンスはスレーブシステム側の環境インピーダンスとは一致 しない。これは本論文において提案する伝達率をマスタシ ステムのみに実装したためだと思われる。しかしながら， すべてのシステムにおいての接触インピーダンス共有は, アイデンティティ比を用いたマルチラテラル制御手法を用 いることで実現することができるため ${ }^{(11)}$ ，目的や用途に応 じてマルチラテラル制御系の構成を変更することが望まし いと言える。また今後の課題として，スレーブシステム側 にも伝達率を実装した場合に関しての伝達率設計を検討す ることがあげられる。

〈4・2・4〉 マスタ間での操作性一致型マルチラテラル制 御の実験結果図 10 にマス夕間での操作性一致型マルチ ラテラル制御の実験結果を示す。本実験はフリーモーショ ンにおいて行った。操作者がまずはじめにマスタシステム 1 を操作し, 次にマスタシステム 2 を操作している。本実 験ではマスタシステム 2 の力情報の伝達率 $\mathbf{T R}_{2}^{f}$ を 0.5 に 設計し, 位置情報の伝達率 $\mathbf{T R}_{2}^{p}$ も 0.5 に設定した。これに

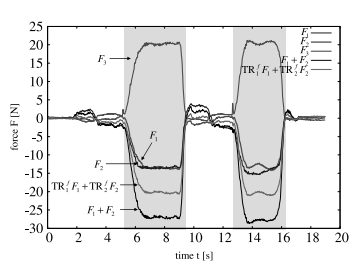

(a) Force responses

$\mathbf{T R}_{1}^{f}=1.0, \mathbf{T R}_{2}^{f}=0.5$

$\mathbf{T R}_{1}^{p}=1.0, \mathbf{T R}_{2}^{p}=2.0$

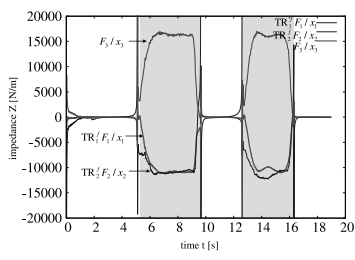

(c) Impedance responses

$\mathbf{T R}_{1}^{f}=1.0, \mathbf{T R}_{2}^{f}=0.5$

$\mathbf{T R}_{1}^{p}=1.0, \mathbf{T R}_{2}^{p}=2.0$

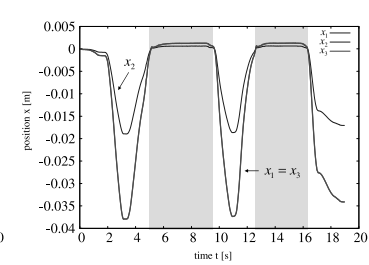

(b) Position responses $\mathbf{T R}_{1}^{f}=1.0, \mathbf{T R}_{2}^{f}=0.5$ $\mathbf{T R}_{1}^{p}=1.0, \mathbf{T R}_{2}^{p}=2.0$
図 9 マスタ間でのインピーダンス一致型マルチ ラテラル制御の実験結果

Fig. 9. Experimental results on multilateral control with transmission ratio for impedance corresponding among master systems. 


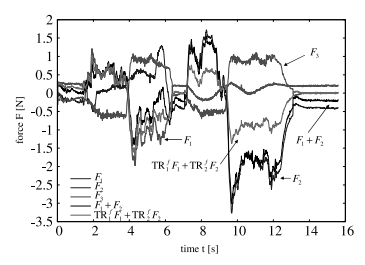

(a) Force responses

$\mathbf{T R}_{1}^{f}=1.0, \mathbf{T R}_{2}^{f}=0.5$

$\mathbf{T R}_{1}^{p}=1.0, \mathbf{T R}_{2}^{p}=0.5$

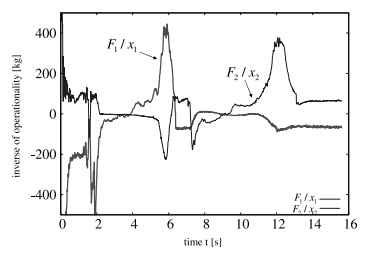

(c) Inverse of operationality responses

$$
\begin{aligned}
& \mathbf{T R}_{1}^{f}=1.0, \mathbf{T R}_{2}^{f}=0.5 \\
& \mathbf{T R}_{1}^{p}=1.0, \mathbf{T R}_{2}^{p}=0.5
\end{aligned}
$$

図 10 マス夕間での操作性一致型マルチラテラル 制御の実験結果

Fig. 10. Experimental results on multilateral control with transmission ratio for operationality corresponding among master systems.

より，操作者がシステムを操作する際のフリーモーション 時, すなわち環境と接触しないときの操作性が一致される。 図 10(c) は各マスタシステムの操作性の逆数を示している。 図 10(c)より，各マスタシステムの操作性が扔扔よそ一致 していることがわかる。実験結果から見られるマスタシス テム間の若干の相違は, 操作の仕方の違いによるものと, 各 マスタシステムでの補償しきれなかった摩擦力の違いによ るものだと考えられる。また，環境接触時にマスタシステ ム側で再現されるインピーダンスはすべてのシステムにお いて一致しない。したがって，実用上は自由動作時には操 作性一致型を適用し，接触時に制御系をインピーダンス一 致型に切り替えることでより良い触覚情報に基づく技術教 育が実現されると考えられる。しかし，その場合には制御 系切り替えの連続性や安定性などといった問題点を明らか にし，解決することが今後の課題として挙げられる。

$\langle\mathbf{4 \cdot 2 \cdot 5}\rangle$ 力次元一致型マルチラテラル制御の実験結果

最後に図 11 に力次元一致型マルチラテラル制御の実験 結果を示す。また網掛け部は発泡スチロール製の環境と接 触している状態を示している。本実験では，マスタシステ ム 2 の位置情報の伝達率 $\mathbf{T R}_{2}^{p}$ のみを 0.5 に設定し，そのほ かの伝達率をすべて 1.0 とした。これにより，すべてのマ スタシステムが力次元に扔いて一致され，マルチラテラル システム間で作用反作用則が人工的に実現されていること がわかる。それに対して，マスタシステム 2 の位置応答は マスタシステム 1 の位置応答の 2 倍となっていることがわ かる。このことは (9) 式が満足されていることを意味して いる。

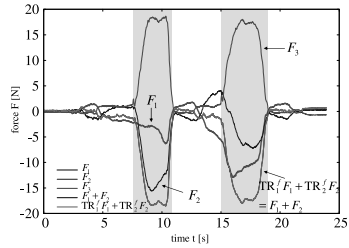

(a) Force responses

$\mathbf{T R}_{1}^{f}=1.0, \mathbf{T R}_{2}^{f}=1.0$

$\mathbf{T R}_{1}^{p}=1.0, \mathbf{T R}_{2}^{p}=0.5$

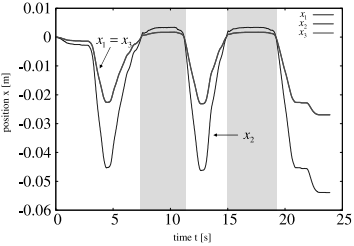

(b) Position responses

$\mathbf{T R}_{1}^{f}=1.0, \mathbf{T R}_{2}^{f}=1.0$

$\mathbf{T R}_{1}^{p}=1.0, \mathbf{T R}_{2}^{p}=0.5$
図 11 力次元一致型マルチラテラル制御の実験結果

Fig. 11. Experimental results on multilateral control with transmission ratio for force dimension corresponding.

以上の実験結果より，提案する伝達率の設計を変えるこ とで様々な種類のマルチラテラル制御が実現できることを 確認した。本論文で提案している伝達率 TR はシステムご とに独立であるため，システムの台数に関係なくマルチラ テラル制御を拡張して用いることが可能である。実際に提 案手法をマルチラテラル制御に基づく技術教育に適用する 際には，訓練者の技術習得レベルに応じた伝達率 TRの設 計が必要となる。特に，人の技術習得レベルを定量的に評 価する手法の開発が望まれる。

\section{5. 結 論}

本論文では触覚情報に基づいた技術教育を実現するため の加速度制御に基づいた新しいマルチラテラル制御を提案 した。技術教育に適応するためのマルチラテラル制御は, 訓 練者の技術の習得レベルに応じて，操作者からのシステム への影響度を変化させられることが必要となる。したがっ て本論文では，各操作者からの影響度を調節するための伝 達率というパラメータを導入した新しいマルチラテラル制 御系を提案した。提案した伝達率の設計を変更することに より，様々なマルチラテラル制御を実現できることを示し た。これらの提案手法の有効性を実験により確認した。提 案した伝達率を導入したマルチラテラル制御手法は，技術 教育システム実現のための基礎技術となりうるだろう。

\section{謝 辞}

本研究の一部は，株式会社エヌ・ティ・ティ・ドコモとの 共同研究「リアルタイムロボティクスの遠隔制御」によっ て行われたことを記すと共に，関係各位に謝意を表す。

(平成 18 年 9 月 25 日受付, 平成 19 年 2 月 15 日再受付)

\section{文献}

(1) B. Hannaford: "A Design Framework for Teleoperators with Kinesthetic Feedback", IEEE Transactions on Robotics and Automation, Vol.5, No.4, pp.426-434 (1989-8)

(2) D.A. Lawrence: "Stability and Transparency in Bilateral Teleoperation", IEEE Transactions on Robotics and Automation, Vol.9, No.5, pp.624-637 (1993-10)

(3) K.H. Zaad and S.E. Salcudean: "Bilateral Parallel Force / Position Teleoperation Control", Journal of Robotic Systems, Vol.19, No.4, pp.155-167 (2002)

(4) K.H. Zaad and S.E. Salcudean: "Transparency in Time-Delayed Systems 
and the Effect of Local Force Feedback for Transparent Teleoperation", IEEE Transactions on Robotics and Automation, Vol.18, No.1, pp.108-114 (2002-2)

(5) Y. Yokokohji and T. Yoshikawa: "Bilateral Control of Master-Slave Manipulators for Ideal Kinesthetic Coupling-Formulation and Experiment”, IEEE Transactions on Robotics and Automation, Vol.10, No.5, pp.605-620 (199410)

(6) K. Kosuge, T. Itoh, T. Fukuda, and M. Otsuka: "Telemanipulation System Based on Task-Oriented Virtual Tool”, Proceedings of the IEEE International Conference on Robotics and Automation, pp.351-356 (1995)

( 7 ) D. Lee and M.W. Spong: "Bilateral Teleoperation of Multiple Cooperative Robots with Delayed Communication: Theory", Proceedings of The IEEE International Conference on Robotics and Automation, ICRA'05, 18th-22nd (2005-4)

(8) D. Lee and M.W. Spong: "Bilateral Teleoperation of Multiple Cooperative Robots with Delayed Communication: Application", Proceedings of The IEEE International Conference on Robotics and Automation, ICRA'05, 18th-22nd (2005-4)

(9) S. Sirouspour: "Modeling and Control of Cooperative Teleoperation Systems", IEEE Transactions on Robotics, Vol.21, No.6, pp.1220-1225 (2005)

(10) S. Katsura, Y. Matsumoto, and K. Ohnishi: "Realization of "Law of Action and Reaction" by Multilateral Control", IEEE Transactions on Industrial Electronics, Vol.52, No.5, pp.1196-1205 (2005-10)

(11) T. Suzuyama, S. Katsura, and K. Ohishi: "Decoupled Haptic Transmission by Multilateral Control", Proceedings of the 9th IEEE International Workshop on Advanced Motion Control, AMC'06-ISTANBUL, pp.334-339 (2006-3)

(12) S.S. Nudehi, R. Mukherjee, and M. Ghodoussi: "A Shared-Control Approach to Haptic Interface Design for Minimally Invasive Telesurgical Training", IEEE Transactions on Control Systems Technology, Vol.13, No.4, pp.588-592 (2005-7)

(13) K. Ohnishi, N. Matsui, and Y. Hori: "Estimation, Identification, and Sensorless Control in Motion Control System", Proceedings of the IEEE, Vol.82, No.8, pp.1253-1265 (1994-8)

(14) T. Murakami, N. Oda, Y. Miyasaka, and K. Ohnishi: "A Motion Control Strategy Based on Equivalent Mass Matrix in Multidegree-of-Freedom Manipulator", IEEE Transactions on Industrial Electronics, Vol.42, No.2, pp.123-130 (1995-4)

(15) T. Doi, K. Osuka, T. Ono, and R. Kawatani: "A Study on the Robust Stability for Disturbance Observers", Transactions of the Society of Instrument and Control Engineers, Vol.34, No.10, pp.1401-1410 (1998-10) (in Japanese) 土井智晴・大須賀公一・小野敏郎・川谷亮治：「外乱オブザーバの ロバスト安定性に対する一考察」, 計測自動制御学会論文集, Vol.34, No.10, pp.1401-1410 (1998-10)

(学生員) 1980 年 2 月 23 日生。 2004 年 3 月早 稲田大学理工学部機械工学科卒業。2006 年 3 月 慶應義塾大学大学院理工学研究科総合デザイン工 学専攻修士課程修了。同年 4 月同大学大学院同専 攻後期博士課程入学。2007 年 4 月より日本学術 振興会特別研究員 (DC2), 現在に至る。主とし てモーションコントロール, ハプティクス, ロボ ティクスの研究に従事。
久保亮吾 (正員) 1983 年 1 月 13 日生。 2005 年 3 月, 慶應

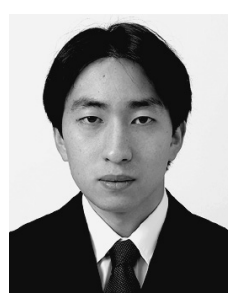
義塾大学理工学部システムデザイン工学科卒業。 2007 年 3 月同大学大学院理工学研究科総合デザ イン工学専攻修士課程修了。同年 4 月日本電信電 話（株）入社。在学中, 主としてモーションコン トロール, ハプティクス, ロボティクスに関する 研究に従事。

大 西 公 平 (上級会員) 1952 年 7 月 25 日生。 1980 年東京

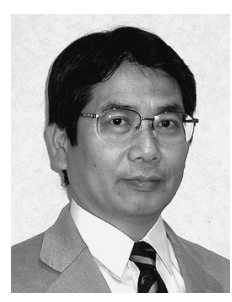
大学大学院工学系研究科電気工学専攻博士課程修 了。同年 4 月慶應義塾大学理工学部電気工学科助 手。現在, 理工学部システムデザイン工学科教授。 工学博士。

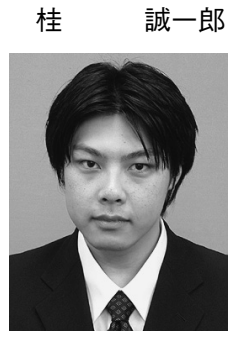

(正員) 1978 年 9 月 23 日生。 2004 年 9 月慶應 義塾大学大学院理工学研究科総合デザイン工学専 攻後期博士課程修了。2003 年 4 月から 2005 年 3 月まで日本学術振興会特別研究員 (DC1 および PD)。2005 年 4 月長岡技術科学大学電気系助手, 2007 年 4 月より同助教, 現在に至る。主として モーションコントロール, ハプティクス, ロボティ クス, メカトロニクスの研究に従事。博士 (工学)。

大 石 潔 (上級会員) 1957 年 10 月 14 日生。1986 年 3 月

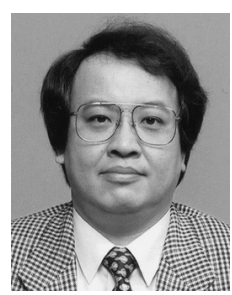
慶應義塾大学大学院工学研究科博士課程修了。大 阪工業大学講師，助教授を経て，1993 年 4 月長 岡技術科学大学電気系助教授，2003 年に同教授, 現在に至る。主として制御工学, パワーエレクト ロニクス，ロボティクスに関する研究に従事。工 学博士。 